\title{
ASPECTS REGARDING THE MANAGEMENT OF UNCONVENTIONAL THREATS
}

\author{
Sergiu-Mihai IONIȚ $\breve{A}^{32}$
}

\begin{abstract}
Our research focuses on analysis of the extended international framework of cooperation for countering unconventional threats and on detailing the modalities of intelligence and police cooperation in the field of contemporary unconventional threats.
\end{abstract}

Keywords: security; cooperation; threats; terrorism; organized crime; prevention; tackling.

\section{INTRODUCTION}

Unconventional threats that may affect the security climate of the southeastern European countries, particularly those that fully engage in the active fight against terrorism, cross-border organized crime and other threats will continue to be active due to power differences between state actors operating in this area.

There is an important necessity for all democratic states of the contemporary world, to apply a common international legal framework in the fight against terrorism, against cross-border criminal organizations in particular, in order to block all terrorism financing sources or any access of extremist organizations to substances, devices and technologies that could seriously affect individual security.

The grounds of all measures to prevent and combat threats and dangers in the field of national security must hinge on certain modalities of action such as finding and eradicating the main causes that favor their emergence and manifestation.

\section{THE PREVENTIVE ACTIONS}

In our opinion, prevention is achieved in several ways:

- prevention by law enforcement, which mainly involves detection and repression of crimes, a post-factum intervention as a warning sign for the future individuals prone to repeat violations of the law;

- prevention by establishing the actions and measures that can be put in the way of criminal activity, an aspect that is essentially related to an adequate strategy and tactics for prevention and combating, adapting in full knowledge of the determinations of the directions and moments of crime;

- prevention by preparing the victim / target for self-defense, by victim understanding both the person and the community, and also intrinsic values -

\footnotetext{
${ }^{32}$ Lieutenant, Special Telecommunication Service, $\mathrm{PhD}$ candidate.
} 
institutions, objectives or goods in connection with which preventive tactics are prepared and applied;

- prevention through measures to improve community relations (socioeconomic, political, ethnic, religious, cultural, etc.);

- prevention by promoting social justice. ${ }^{33}$

Preventive activity consists of measures and actions developed and applied in a logical succession that are able to initiate authentic causal processes, aimed to destroy, dissolve or cease the normal functioning of the potential contributing factors of the crime. Taking into account the aspects presented above, we can speak of two types of preventive actions.

The first type is the normative-formative action. This means a complex set of measures that act in the sense of shaping people and groups of people, the community, in the spirit of respect for the law, instructions, rules of conduct, respect for national, social, political, military values, etc.

The second type of preventive action is aimed at eliminating situations, facts that can influence a person or can be used by a person to commit crimes.

Inter-departmental cooperation in the fight against crime, drug trafficking and terrorism is the key or determining element. Every institution committed to combating these unconventional threats for national security must maintain full order in its own structure. The government needs to know what each one is doing and how the co-operation is being made between the parties of the system. Failure in this area can have significant international implications.

Modern criminals and terrorists no longer take into account national borders. They operate as an amalgam of foreigners and residents, always on the move, traveling across borders and continents. This reality frustrates, confuses and discourages jurisdictional institutions.

The role of law enforcement, security and military forces in combating unconventional threats to national security must be in support of the law. Gathering and exchanging information, joint training activities, taking part in the integrated development of exercises are elements of cooperation in security issues among the components of the national defense system.

Public order institutions, national security entities and the army must cooperate on security issues and support each other in the fight against strategic crime and its essential elements: organized crime, drug trafficking and terrorism.

The threats to security are currently manifested in complex and atypical forms, coming from multiple directions, which makes it difficult to prevent and exclude them.

\footnotetext{
${ }^{33}$ Koppell Carla, Sharma Anita, Preventing the Next Wave of Conflict. Understanding Non-Traditional Threats to Global Stability Report of the Non-Traditional Threats. Working Group, Woodrow Wilson International Center for Scholars, Washington, D.C.

https://www.wilsoncenter.org/sites/default/files/media/documents/article/nontradthreat.pdf, valid at 06.06.2021.
} 
All threats that follow the process of change must be taken into account when analyzing Romania's national security, perceived as a state of the nation that ensures the protection and defense of the national interest objectives.

New security challenges will require new approaches with reference to risk and threat management, a concept that must be proactive.

The analysis of threats must start from the fact that, under certain conditions, these can turn into real imminent dangers or even aggressions, and increase or decrease of the importance of each will depend on a set of circumstances determined by the evolution of Romania's geopolitical and geostrategic situation, as well as interests of the great powers for this area and the European security system.

Western experience shows that the change of meaning or the transition from a general reactive attitude (reducing the effects of an event that occurred) to a proactive attitude (measures to prevent an event from occurring) is the result of reasoning aimed at reducing risk up to the level of accessibility in society. Application of specific risk management techniques in the development of national security and defense policies creates the conditions for detecting the most efficient ways of action for fulfilling the national interests and objectives from the perspective of confronting potential risks. A decision based on the assessment of a threat, in the absence of a hierarchy of national interests, may be considered an action with possible undesirable effects on national security.

Landmarks and threat analysis indices cannot exclude the permanent knowledge of the answers to the questions, such as: what are the most obvious threats to national security? Are the possibilities and measures for their current management sufficient? And if not, what other actions and measures should supplement them? What information flows can highlight the existence and evolution of certain threats? Is the state of national security properly investigated? Are the types of analysis appropriate? Do the analyses make it possible to measure the status of the security system at a given time? Can dysfunctional processes be identified through the analyses undertaken?

\section{THE COOPERATION}

In this architecture of national security, intelligence services represent external and internal determinations of conditioning, created to ensure the existence of the Romanian state. The new types of threats that characterize any community, with a strong cross-border and transnational footprint, lead to the development of common, concrete and realistic strategies because, in fact, national and international collective security is threatened. This reality requires wide cooperation and participation in solving some aspects of interest of all information structures.

The cooperation agreements concluded by Romania with the Eastern European states in the field of prevention, combat, detection and investigation of 
crimes related to organized crime provide for police cooperation with specialized bodies in these states in the fields of: illegal cultivation, production, manufacture and drug trafficking; illegal production, trade and use of chemicals essential for the illegal production of narcotics; trafficking in weapons, ammunition, explosives and other materials that can be used to make lethal artisanal means, as well as trafficking in toxic substances; illegal international economic activities and legalization of income obtained (money laundering) from illicit activities, suspicious economic and banking transactions and investment abuses; smuggling; illicit activities related to migration, illegal border crossings and illegal trafficking in human beings; sexual exploitation of women and minors or children; counterfeiting and forgery of banknotes, credit cards, documents, securities, as well as any identity document; crimes against human life and property; illicit trafficking in precious stones and metals, intellectual property and valuables from the cultural and historical heritage; corruption; ecological crimes; abduction and trade in human organs; maritime crime (maritime fraud, piracy); theft and illegal vehicle trafficking. ${ }^{34}$

These mutations were produced in the system for combating unconventional threats as a result of Romania's integration into the European Union. The integration in the European and Euro-Atlantic structures is a fundamental option of the Romanian state, a point of convergence of all political forces in Romania. Achieving the required levels of performance in order to meet the objectives of the common foreign and security policy requires our country to comply with a series of conditions regarding: coherent harmonization of technical structures, communication networks, information systems; harmonization and coherence of the operational structures involved; harmonization and coherence of legislation and regulation in full compatibility with the acquits and good practice of the European Union; achieving a level of functioning of computer data protection institutions and individual freedoms in full compatibility with the acquits and good practices of the European Union.

The National Strategy for Preventing and Combating Terrorism sets "benchmarks for a systematic approach to the terrorist phenomenon" 35 . Of course, in this case, the activities specific to organized crime and corruption related to terrorism are targeted and incriminated, directly or indirectly. The document defines terrorism as a type of social expression, classifies it according to several criteria (motivational tool, forces involved, area of manifestation), fixes the factors and mechanisms involved in the dynamics of the terrorist phenomenon and establishes the entities involved in terrorist issues and targets. After defining these concepts, the major objectives of the national action to prevent and combat terrorism are clearly set out, as follows:

\footnotetext{
${ }^{34} \mathrm{https}: / /$ www.europol.europa.eu/partners-agreements/member-states/romania, valid at 06.06.2021.

35 The National Strategy for Preventing and Combating Terrorism, https://www.google.com/search? client=firefox-b-d\&q=The+National+Strategy+for+Preventing+and+Combating+Terrorism+
} 
a) identification, monitoring and constant assessment of all risks and threats, respectively of vulnerabilities on national security coordinates, engendered by concerns, intentions, actions and inactions, facts and both endogenous and exogenous phenomena that are or may be constituted in elements that contribute to the emergence, development and specific manifestation, outside and inside national borders, of terrorism, as well as to its fueling or favoring in any way;

b) the protection of the national territory (respectively of the local population and objectives, of the residents and foreign objectives) from the subsumed / associated activities of terrorism, through all the necessary categories of institutionalized activities aiming at: preventing the occurrence of international terrorism, in all possible forms of manifestation; reducing the risks to Romania's security, generated by the nuclei of international terrorism which, under various covers, could be implanted and act against targets on the country's territory, independently or in association with various other foreign and / or domestic entities;

c) the protection of the Romanian citizens and objectives from abroad from activities subsumed / associated with terrorism, regardless of their origin and forms of manifestation;

d) preventing the involvement of Romanian citizens and foreign residents in Romania in activities subsumed / associated with international terrorism, regardless of the area of development, their objectives or targets;

e) participation in international efforts to prevent and combat the terrorist phenomenon in various geographical areas, through: active contributions to bilateral / multilateral initiatives aimed at identifying and operationalizing the most effective political and diplomatic actions, regulations and other normative instruments, as well as international mechanisms inter-institutional cooperation meant to prevent the appearance, development and manifestation of the terrorist phenomenon, as well as to combat the activities subsumed / associated with it; the transposition in the national normative framework and in the current activities carried out by the Romanian state, internally and in the external relations, of the obligations assumed or incumbent on it according to the international agreements in such problems, to which our country is a party; exchanges of information and law enforcement cooperation on intentions, concerns and actions of a nature or with a possible terrorist purpose or which promote the emergence, development and manifestation of terrorism; participation with specialized armed forces in multinational military operations, carried out in accordance with UN resolutions, aimed at materializing the objectives of ensuring international security and stability in preventing and combating the terrorist phenomenon.

In order to materialize the objectives provided in the National Strategy for Preventing and Combating Terrorism, the National System for Preventing and Combating Terrorism was established as a "mechanism for ensuring, 
organizing and conducting in a unitary vision, inter-institutional, cross - sectoral cooperation, categories of tasks subject to national action in the field of counterterrorism", which operates on the basis of the General Protocol on the organization and functioning of the National System for Preventing and Combating Terrorism concluded among participants, under the strategic leadership of the Supreme Defense Council Romania and Romanian Intelligence Service.

The general and specific objectives of the content of the National Strategy for Combating Organized Crime $^{36}$ were established taking into account the provisions of normative acts in the field that Romania has ratified, as well as the programmatic documents on our country's accession to the European Union, observations, conclusions and recommendations following a careful analysis of this process.

In our opinion, the objectives are: achieving compatibility, from an institutional and functional point of view, at the level of European structures involved in combating cross-border organized crime by improving legislation and optimizing the activities carried out by these structures; inter-institutional cooperation to be achieved at the highest standards in order to combat unconventional threats effectively; the use of information technology in order to increase the efficiency of operational activities, to create and computerize databases and to interconnect specialized structures; combating drug trafficking and consumption, through actions that increase drug seizures and reduce drug demand; illegal trafficking in human beings and violent crimes should be kept to a declining level; increasing the level of actions taken to prevent the trafficking of strategic materials; establishing the necessary measures to prohibit money laundering by organized crime networks; reduction of counterfeiting in the financial and economic sector, as well as reduction of fraud committed by means of counterfeit payment instruments; reducing corruption.

Reducing actions to combat threats to the security of the country and allies only by using military-specific equipment and means is a great mistake. Among the measures needed to eliminate this major shortcoming are the harmonization of security policies in that segment and the implementation of a single early warning system involving all components of national security as part of a complex international system capable of eliminating the shortcomings existing nowadays.

The efficiency of this complex international system will be ensured by:

- the conceptual component - materialized through a set of documents related to the theories, tactics, techniques and procedures necessary to fulfill the mission, as well as their study, understanding and acquisition by the staff involved;

\footnotetext{
36 STRATEGIA NAȚIONALĂ de combatere a criminalității organizate în perioada 20042007 | Hotărâre 2209/2004, https://lege5.ro/Gratuit/guydqmjz/strategia-nationala-de-combatere-a-criminalitatii-organizate-inperioada-2004-2007-hotarare-2209-2004?dp=geztonzyg44te.
} 
- the action component - involves the realization of structural entities specific to these missions both within and outside the armed forces, equipping these structures with equipment, technology and materials appropriate to their missions and necessary for the integration of various components in early warning systems of alliances or coalitions preparing and conducting multinational operations;

- elaboration of the legislative and functional framework, specific to crisis management, focusing on both the provisions of international regulations and the experience gained during the last decades in resolving crises and non-military conflicts or those who did not know the stage of military conflict, precisely due to actions threat prevention.

The European Union has, in recent years, considerably strengthened its legal framework on the prevention of money laundering and terrorist financing, as follows:

- The 4th Directive (EU) 2015/849 on combating money laundering was adopted in May 2015 and was to be transposed by the Member States by June 2017. In the framework of the Action Plan to strengthen the fight against terrorist financing, adopted in February 2016, and in response to the April 2016 Panama Papers disclosures;

- The 5th Directive (EU) 2018/843 on combating money laundering was adopted in April 2018 and Member States must transpose it into national law by January 2020. This review increases the transparency of information on real beneficiaries, provides financial intelligence units with wider access to information, strengthens cooperation between supervisors and regulates virtual currencies and prepaid cards to better combat terrorist financing. With regard to the financial sector, the new rules on the exchange of information and the dissemination of information should significantly improve cooperation between prudential supervisors and the fight against money laundering / terrorist financing and strengthen the role of the European Banking Authority in enforcing EU rules; strengthening cooperation in the fight against money laundering and terrorist financing;

\section{CONCLUSIONS}

As an active partner in international relations in the field of the fight against terrorism, Romania has signed or ratified a series of documents (conventions, declarations, etc.) meant to legally sanction terrorism. Thereby, terrorism and its concrete forms of manifestation are inserted in several international legal documents, most of which have entered into force.

At national level, the prevention and combating of unconventional threats is carried out according to the provisions of the international conventions, to which Romania is a party. 
Our opinion is that the current register of threats to national security has required the development of operational capacity for understanding, knowledge, prevention and counteracting, as well as its adaptation to the requirements of the foreseeable evolution of potential risk factors for national security.

There is no doubt that the priority in the fight against terrorism, cross-border organized crime and other forms of unconventional threats originates from the very constitutional need to defend the country's sovereignty and independence, territorial integrity, state unity, peace and security.

\section{BIBLIOGRAPHY}

- National Defence Strategy 2020-2024,,Together for a safe and prosperous Romania in a world markedby new challenges", Romania Presidential Administration, Bucharest, 2020; https://www.presidency.ro/files/userfiles/ National_Defence_Strategy_2020_2024.pdf

- National Strategy to Fight Organized Crime In The Period 2004-2007, http://www.just.ro/strategia-nationala-impotriva-criminalitatii-organizate2021-2024/

- The National Strategy for Preventing and Combating Terrorism, https://www.google.com/search?client=firefox-b-d\&q=The+National+ Strategy+for+Preventing+and+Combating+Terrorism

- Cîrnici Luminița Ludmila, European terrorism and the impact on national security, Top Form Publishing House, Bucharest, 2017.

- Koppell Carla, Sharma Anita, Preventing the Next Wave of Conflict. Understanding Non-Traditional Threats to Global Stability Report of the Non-Traditional Threats. Working Group, Woodrow Wilson International Center for Scholars, Washington, D.C.

https://www.wilsoncenter.org/sites/default/files/media/documents/article/non tradthreat.pdf, valid at 06.06.2021.

- https://www.europol.europa.eu/partners-agreements/member-states/romania, valid at 04.06.2021. 